\title{
The Effect of Protracted Exposure to Radiation on Liver Injury: A Cohort Study of Industrial Radiographers in Xinjiang, China
}

\author{
Qing Sun ${ }^{\dagger}$, Weiming Mao ${ }^{\dagger}$, Haiyue Jiang, Xiaoyue Zhang, Jing Xiao and Yulong Lian * \\ Division of Occupational and Environmental Health, College of Public Health, Nantong University, \\ Se Yuan Road, No. 8, Nantong 226019, China; SunQ_9005@163.com (Q.S.); mwm457419340@163.com (W.M.); \\ echo_jhy@163.com (H.J.); m18862920791@163.com (X.Z.); Xiaoj_1980@163.com (J.X.) \\ * Correspondence: lianyulong444@163.com; Tel.: +86-513-8501-2912 \\ t These authors contribute equally to this paper.
}

Received: 15 November 2017; Accepted: 1 January 2018; Published: 4 January 2018

\begin{abstract}
Background: At present, a large number of studies indicate that high dose ionizing radiation exposure is an important risk factor for liver damage. Whether protracted exposure to low external doses of ionizing radiation could induce liver injury is unclear. The aim of this study was to assess the risk of liver injury following protracted exposure to occupational radiation compared to a group of unexposed workers. Methods: A three-year cohort study was initiated in Xinjiang, China in 2010 and included 508 industrial radiographers and 2156 unexposed workers. The incidence of liver injury was assessed clinically based on the evaluation of alanine aminotransferase (ALT) and aspartate transaminase (AST) levels. Logistic regression was used to examine whether radiation is a risk factor for liver injury. Results: Compared with the unexposed group, protracted radiation exposure was found to be a risk factor for liver injury. Sex, age at baseline and alcohol consumption were not associated with liver injury. However, hypertension was a risk factor for liver injury. The association between cumulative recorded radiation dose and liver injury was not found in this study. Conclusions: These findings indicate that protracted exposure to radiation is a risk factor for liver injury.
\end{abstract}

Keywords: liver injury; cohort studies; occupational exposure; radiation; risk factors

\section{Introduction}

Radiologic technology, a non-destructive technique [1,2], has been widely used in many fields, such as agriculture, medical treatment and the manufacturing industry. With the development of science and technology, the number of industrial radiographers has quickly increased in recent years and is one of the most important populations exposed to ionizing radiation. It has been reported that ionizing radiation exposure can induce biological effects on human health [3], with both early and late effects of radiation in normal tissues and organs [3,4]. Previous studies on patients without liver disease who undergo radiation therapy have proved that exposure to ionizing radiation can induce hepatic dysfunction or even liver cancer [5-8]. Data from cohorts of atomic bomb survivors indicate that exposure to radiation induced a high prevalence of hepatitis $B$ and hepatitis $C$ infection [9] and liver cirrhosis [6,9]. Several studies have shown that acute high dose radiation $(>10 \mathrm{~Gy})$ can cause significant structural damage in the liver and hepatic toxicity [10]. Experiments carried out on rats showed that systemic exposure to a single dose of 6 Gy gamma radiation could induce a significant elevation in alanine aminotransferase (ALT) [11]. An epidemiology study on radiotherapy of cancer in childhood and adolescence indicated that radiation of the liver (mean liver dose $=5 \mathrm{~Gy}$ ) could cause low hepatotoxicity [12]. The studies mentioned above indicate that exposure to high dose ionizing radiation can induce liver damage. However, the International Commission on Radiological Protection 
(ICRP) recommended that the annual effective dose limits for radiation workers should no more than $20 \mathrm{mSv}$, and this criterion has been implemented in most countries [13]. The effects of protracted exposure to this low external dose of ionizing radiation on liver injury is not clear. Researches have shown that liver is considered a radiation sensitive organ [12,14]. Animal experimental data indicate that low dose radiation (single dose ranging from 0.02 to $1.0 \mathrm{~Gy}$ ) can increase liver inflammation [15], which suggests that low dose radiation exposure may negatively affect liver function and result in the development of liver disease.

The aim of this study was to evaluate the relationship between protracted exposure to low dose radiation and liver injury in industrial radiographers, and complemented the current risk estimates that mainly focus on high-dose or single-dose radiation exposure-induced liver injury. All of the industrial radiographers predominantly exposed to $X$-ray and $\gamma$-ray radiation, and their liver function were assessed each year during the follow-up period. After adjusting for other liver injury confounding risk factors, this study estimated the risk of liver injury from low external doses of ionizing radiation exposure, compared with the unexposed group.

\section{Materials and Methods}

\subsection{Study Population and Follow Up}

The population in this study consisted of petrochemical workers who were registered at the Karamay Center for Disease Control (CDC, Karamay, China). All the radiographers included in this cohort were predominantly exposed to external X-ray and $\gamma$-ray radiation and the dose was below the dose limit of the Protection of Ionizing Radiation and Basic Safety Standard of Radiation Source in China, $20 \mathrm{mSV}$. When a radiographer's radiation dose exceeded the limit, the worker was removed from his position. In 2010, baseline data of medical examination results and baseline questionnaire for 766 radiographers and 3610 control workers were obtained. The contents of baseline questionnaire include social demographic characteristics and lifestyle factors such as sex, age at baseline, education level, and marital status, history of cigarette smoking and alcohol consumption. In all, 97 radiographers and 940 non-exposed workers were excluded because of loss to follow-up, had a history of liver disease and worked for less than one year at baseline. 145 radiographers and 223 non-exposed workers were also excluded because of elevated ALT and aspartate transaminase (AST) at baseline. Furthermore, participants with viral hepatitis $(n=46)$, fatty liver disease $(n=34)$, cholecystitis $(n=0)$, gallstones $(n=208)$ were also excluded. The final analytic cohort was comprised of 2683 participants including 508 exposed workers and 2175 non-exposed workers. In addition to the social demographic characteristics mentioned above, other possible risk factors that could induce liver injury including hypertension and diabetes were also assessed during the baseline period according to a self-reported questionnaire and occupational health examination database. Fatty liver, cholecystitis and intrahepatic gallstones diagnosed annually by an abdominal ultrasound examination during the baseline and follow up period. Follow-up was from January 2010 to liver injury diagnosis, loss of follow up, retirement or 31 December 2013. During the follow-up period, annual occupational health examinations were conducted in Karamay CDC, and all participants attended the examination. According to the rules of the People's Republic of China on the prevention and control of occupational diseases, new cases with liver injury were identified. The research protocol for this cohort study was approved annually by the ethics committee of Xinjiang Medical University. All participants enrolled in the study provided written informed consent.

\subsection{Clinical Evaluation of Liver Injury}

Annual occupational health examinations were conducted in the medical center at the Department of Occupational Health, Karamay CDC. All workers had a complete physical examination as well as venous blood collection, which were used to evaluate the ALT and AST levels. The workers also complete the abdominal ultrasound examination, an important way to detect possible abnormal 
liver morphology. Liver enzyme activity and other test results were compared to normal laboratory standards of Karamay CDC.

Previous studies have suggested that serum ALT and AST are sensitive and reliable indicators of liver disease [16], and can satisfy most of the criteria for a screening test [17]. We accepted the upper limit of normal (ULN) value of ALT and AST as $40 \mathrm{IU} / \mathrm{L}$ (IU Refers to the amount of enzyme that converts 1 micromolar substrate per minute under specific conditions or the amount of enzyme that converts 1 micromolar related moiety in the substrate) [18,19]. Because of the criterion of define liver injury around the world are still controversial, and the definition of radiation induced liver injury is unclear. The Asian-Pacific clinical practice guidelines believed that serum ALT level is raised if it is more than twice ULN, and previous USA studies recommended that the concentration of ALT or AST more than twice normal was the criterion of toxin-induced hepatic injury [20-22]. So, we use this criterion to define liver injury in our study.

\subsection{Radiation Dosimetry}

The consistent dosimetric instrument, thermoluminescent dosimeter (TLD), was used to monitor the exposure to $X$-rays and $\gamma$-rays of the industrial radiographers, who were registered at the Karamay CDC. Each of the radiographers was provided one TLD, and worn it on the right chest over the lead protective garment. Based on the TLD, we get the radiation dose record, and calculate dose after upward adjustment, using the apron attenuation factor, if the badge was reported to have been worn under the apron. Adjusted for the use of protective lead aprons, the estimated absorbed doses of liver will be more accurate.

Job exposure matrix (JEM) is a common occupational risk assessment method [23,24], that can be used to assess the contribution of occupationally exposed occupational risk factors for the disease [23]. Due to the loss of some of the individual test data in previous years, we use the average dose of other research years of the same work type to supplement the missing data, and evaluate the cumulative radiation dose based on the JEM. Due to some workers engaged in radiation work only a few months, and it is difficult to estimate their first year's radiation exposure dose. So, we exclude workers with a working history of less than 1 year. The cumulative radiation dose was calculated according to the following equation:

$$
\mathrm{D}=\sum_{i=1}^{n} X_{i}
$$

$\mathrm{D}$ is cumulative radiation exposure dose $(\mathrm{mSv}), X_{i}$ is the radiation exposure dose in the $i$-th year of the industrial radiographers engaged in radiological work.

\subsection{Confounding Factors}

Several factors were considered as potential confounders which were extracted from baseline data and defined before we analyze the liver injury. Age was categorized into less than 30 years old, 30-year, 40-year and 50-year. Education was categorized into junior high, high school and college. Information regarding smoking and alcohol consumption were also collected. Alcohol consumption was based on the question: 'Do you drink more recently?' The response options were never, seldom, sometimes, often and always. We categorized the response 'never' into never alcohol consumption, 'seldom' and 'sometimes' into alcohol consumption occasionally, 'often' and 'always' into alcohol consumption frequently [25]. Smoking was based on the question: 'Do you smoke more recently?' The response options were never, occasionally and frequently [26]. World health organization (WHO) recommended that the hypertension definition was systolic blood pressure greater than or equal to $140 \mathrm{mmHg}$ and/or diastolic blood pressure greater than or equal to $90 \mathrm{mmHg}$. WHO also defined diabetes as fasting plasma glucose value $\geq 7 \mathrm{mmol} / \mathrm{L}$ [27]. We categorized hypertension and diabetes according to this definition. 


\subsection{Statistical Methods}

The demographic and clinical variables of industrial radiographers and control workers were described and compared using the chi-square test. We calculated risk ratios (RR) and $95 \%$ confidence intervals (CI) with unadjusted logistic regression model and multiple logistic regression model to analyze the effects of protracted low-dose radiation exposure on liver injury. The multiple model was adjusted for sex, education, age at baseline, marital status, smoking, alcohol consumption, hypertension and diabetes.

To evaluate the independent effects of each confounding factor on the incidence of liver injury among industrial radiographers, we presented crude and adjusted multivariate model. The multivariate model included the following baseline values: sex, age at baseline, marital status, education level, smoking, alcohol consumption, hypertension, diabetes and cumulative recorded radiation adjustment. The unadjusted model showed the single risk factors. The cumulative radiation dose was calculated according to JEM mentioned above. The relationship between the cumulative radiation dose and the relative risk for liver injury was investigated by trend analysis, using three equal dose categories (>0-5.167, 5.168-31.540, 31.541-110.835 mSv).

\section{Results}

In this study, 508 industrial radiographers 2175 non-exposed workers were analyzed. The fluctuation range of ALT was 0-301 U/L, and AST was 2-106 U/L. Table 1 describes the characteristics of the industrial radiographers and the unexposed worker group. The total number of participants in this study was divided into four groups according to age at baseline (age less than 30 years old, 30-year, 40-year, 50-year). The mean age of the industrial radiographers at baseline was 36.74 years (range, 20-65 years), and 89.53\% were male. In the unexposed workers, the mean age at baseline was 38.25 years (range, $18-59$ years), and $61.35 \%$ were male. The frequency of smoking and high school education level in industrial radiographers were higher than those in the unexposed group. Sex and age at baseline, marital status, education level, alcohol consumption, hypertension, diabetes and gallstones were significantly different between the industrial radiographers and the unexposed group.

Table 1. Characteristics of the study population.

\begin{tabular}{|c|c|c|c|}
\hline Variables & Unexposed Group $(n=2175)$ & Industry Radiographer $(n=508)$ & $p$ Value \\
\hline \multicolumn{4}{|l|}{ Sex } \\
\hline Male & $1407(64.69)$ & $454(89.37)$ & \\
\hline Female & $768(35.31)$ & $54(10.63)$ & 0.0001 \\
\hline \multicolumn{4}{|l|}{ Age at baseline } \\
\hline$<30$ & $357(16.41)$ & $144(28.35)$ & \\
\hline $30-$ & $771(35.45)$ & $137(26.97)$ & \\
\hline $40-$ & 925 (42.53) & 194 (38.19) & \\
\hline $50-$ & $122(5.61)$ & $33(6.50)$ & 0.0001 \\
\hline \multicolumn{4}{|l|}{ Marital status } \\
\hline Single & $370(17.01)$ & $108(21.26)$ & \\
\hline Married/living with a partner & $1072(49.29)$ & $255(50.20)$ & \\
\hline Divorced & $207(9.52)$ & $35(6.89)$ & \\
\hline Widowed & $526(24.18)$ & $110(21.65)$ & 0.037 \\
\hline \multicolumn{4}{|l|}{ Education level } \\
\hline Junior high & $150(6.90)$ & $39(7.68)$ & \\
\hline High school & 859 (39.49) & $265(52.17)$ & \\
\hline College & $1166(53.61)$ & $204(40.16)$ & 0.0001 \\
\hline \multicolumn{4}{|l|}{ Smoking } \\
\hline Never & $1340(61.61)$ & $284(55.91)$ & \\
\hline Occasionally & $216(9.93)$ & $82(16.14)$ & \\
\hline Current & $619(28.46)$ & $142(27.95)$ & 0.0001 \\
\hline
\end{tabular}


Table 1. Cont.

\begin{tabular}{cccc}
\hline Variables & Unexposed Group $\mathbf{( n = 2 1 7 5 )}$ & Industry Radiographer $(\mathbf{n}=\mathbf{5 0 8})$ & $p$ Value \\
\hline Alcohol consumption & & & \\
Never & $445(20.46)$ & $154(30.31)$ & \\
Occasionally & $1172(49.29)$ & $208(40.94)$ & 0.0001 \\
Current & $658(30.25)$ & $146(28.74)$ & \\
\hline Hypertension & & & \\
No & $1580(72.64)$ & $401(78.94)$ & 0.004 \\
Yes & $595(27.36)$ & $107(21.06)$ & \\
\hline Diabetes & & $507(99.80)$ & \\
No & $2157(99.17)$ & $1(0.20)$ & \\
Yes & $18(0.83)$ & & \\
\hline 0 & & & \\
\hline Cumulative recorded radiation dose & $2175(100)$ & 169 & \\
5.168-31.540 & & 165 & \\
$31.541-110.835$ & &
\end{tabular}

The prevalence, unadjusted and adjusted logistic RR, and 95\% CIs of liver injury are shown in Table 2. The incidence of liver injury in the low-dose radiation exposure group was approximately two to three times more frequent than that in the unexposed group. In the unadjusted analysis, the radiation exposure group had a total RR of 2.642 (95\% CI 1.850 to 3.772) compared with the non-radiation exposure group. However, after adjusting the confounders, the total RR decreased to 2.227 (95\% CI 1.526 to 3.252). Both the unadjusted and adjusted analyses showed that after differentiating sex, age at baseline, marital status, education level, smoking and alcohol consumption, the associations of protracted low-dose radiation exposure and liver injury remained significant among males, age at baseline between 30 and 50 years old, those who married/living with a partner, those who received higher education (high school and college), those who never smoked and smoking/drinking occasionally and frequently. Particularly, in the unadjusted analysis, protracted low-dose radiation exposure is not a risk factor for liver injury in females. After adjustment of the confounders, this association became significant. However, in the unadjusted analysis, protracted low-dose radiation exposure is a risk factor for liver injury in those who never consumed alcohol and singles; when we adjust the potential confounders, this association became non-significant.

Table 2. Logistic regression RR and 95\% CI of Liver injury in those exposed to radiation compared with unexposed workers.

\begin{tabular}{|c|c|c|c|c|c|c|}
\hline \multirow{2}{*}{ Variables } & \multirow{2}{*}{$\begin{array}{c}\begin{array}{c}\text { Non-Radiation } \\
\text { Exposure }\end{array} \\
\text { Cases/Total }\end{array}$} & \multirow{2}{*}{$\begin{array}{c}\begin{array}{c}\text { Radiation } \\
\text { Exposure }\end{array} \\
\text { Cases/Total }\end{array}$} & \multicolumn{2}{|c|}{ Un-Adjusted } & \multicolumn{2}{|c|}{ Adjusted * } \\
\hline & & & RR & $95 \% \mathrm{CI}$ & $\mathbf{R R}$ & $95 \% \mathrm{CI}$ \\
\hline Total & $90 / 2175$ & $52 / 508$ & 2.642 & $1.850-3.772^{\mathrm{a}}$ & 2.227 & $1.526-3.252^{\mathrm{a}}$ \\
\hline \multicolumn{7}{|l|}{ Sex } \\
\hline Male & $69 / 1407$ & $48 / 454$ & 2.293 & $1.560-3.368^{a}$ & 2.161 & $1.447-3.227^{\mathrm{a}}$ \\
\hline Female & $21 / 768$ & $4 / 54$ & 2.846 & $0.941-8.608$ & 3.319 & $1.062-10.37^{\mathrm{a}}$ \\
\hline \multicolumn{7}{|l|}{ Age at baseline } \\
\hline$<30$ & $27 / 357$ & $18 / 144$ & 1.746 & $0.929-3.281$ & 1.562 & $0.805-3.029$ \\
\hline $30-$ & $31 / 771$ & $16 / 137$ & 3.156 & $1.676-5.946^{a}$ & 2.780 & $1.402-5.512^{\mathrm{a}}$ \\
\hline $40-$ & $26 / 925$ & $15 / 194$ & 2.898 & $1.504-5.580^{\mathrm{a}}$ & 2.835 & $1.404-5.724^{\mathrm{a}}$ \\
\hline $50-$ & $6 / 122$ & $3 / 33$ & 1.933 & $0.457-8.184$ & 1.976 & $0.408-9.564$ \\
\hline \multicolumn{7}{|l|}{ Marital status } \\
\hline Single & $25 / 370$ & $15 / 108$ & 2.226 & $1.128-4.393^{\mathrm{a}}$ & 1.973 & $0.935-4.166$ \\
\hline $\begin{array}{l}\text { Married/living } \\
\text { with a partner }\end{array}$ & $36 / 1072$ & $25 / 255$ & 3.128 & $1.841-5.314^{\mathrm{a}}$ & 2.855 & $1.639-5.078^{\mathrm{a}}$ \\
\hline Divorced & $6 / 207$ & $2 / 35$ & 2.030 & $0.393-10.489$ & 1.702 & $0.277-10.449$ \\
\hline Widowed & $23 / 526$ & $10 / 110$ & 2.187 & $1.010-4.737^{\mathrm{a}}$ & 2.018 & $0.892-4.566$ \\
\hline
\end{tabular}


Table 2. Cont

\begin{tabular}{|c|c|c|c|c|c|c|}
\hline \multirow{2}{*}{ Variables } & \multirow{2}{*}{$\begin{array}{c}\begin{array}{c}\text { Non-Radiation } \\
\text { Exposure }\end{array} \\
\text { Cases/Total }\end{array}$} & \multirow{2}{*}{$\begin{array}{c}\begin{array}{c}\text { Radiation } \\
\text { Exposure }\end{array} \\
\text { Cases/Total }\end{array}$} & \multicolumn{2}{|c|}{ Un-Adjusted } & \multicolumn{2}{|c|}{ Adjusted * } \\
\hline & & & RR & $95 \%$ CI & RR & $95 \%$ CI \\
\hline \multicolumn{7}{|l|}{ Education level } \\
\hline Junior high & $6 / 150$ & $3 / 39$ & 2.000 & $0.477-8.384$ & 1.437 & $0.287-7.192$ \\
\hline High school & $36 / 859$ & $25 / 265$ & 2.381 & $1.401-4.046^{\mathrm{a}}$ & 2.134 & $1.215-3.746^{\mathrm{a}}$ \\
\hline College & $48 / 1166$ & $24 / 204$ & 3.106 & $1.856-5.196^{\mathrm{a}}$ & 2.462 & $1.411-4.297^{\mathrm{a}}$ \\
\hline \multicolumn{7}{|l|}{ Smoking } \\
\hline Never & $54 / 1340$ & $24 / 284$ & 2.198 & $1.335-3.621^{\mathrm{a}}$ & 1.865 & $1.090-3.192^{\mathrm{a}}$ \\
\hline Occasionally & $2 / 216$ & $10 / 82$ & 14.861 & $3.181-69.424^{\mathrm{a}}$ & 15.634 & $2.611-93.620^{\mathrm{a}}$ \\
\hline Frequently & $34 / 619$ & $18 / 142$ & 2.498 & $1.366-4.566^{\mathrm{a}}$ & 2.086 & $1.105-3.938^{a}$ \\
\hline \multicolumn{7}{|l|}{$\begin{array}{c}\text { Alcohol } \\
\text { consumption }\end{array}$} \\
\hline Never & $19 / 445$ & $16 / 154$ & 2.600 & $1.301-5.194^{\mathrm{a}}$ & 2.049 & $0.976-4.303$ \\
\hline Occasionally & $41 / 1072$ & $19 / 208$ & 2.528 & $1.436-4.451^{\mathrm{a}}$ & 2.342 & $1.283-4.275^{\mathrm{a}}$ \\
\hline Frequently & $30 / 658$ & $17 / 146$ & 2.759 & $1.477-5.151^{\mathrm{a}}$ & 2.238 & $1.168-4.288^{\mathrm{a}}$ \\
\hline
\end{tabular}

In the industrial radiographers, logistic regression was used to estimate the risk factors associated with the incidence of liver injury. After adjusting for basic social demographic characteristics and all possible confounding risk factors, two models are shown in Table 3. The unadjusted model and adjusted model indicated that hypertension was a significant risk factor for liver injury. In addition, increased cumulative radiation dose and age at baseline $(p>0.05)$ were not associated with increased risk of liver injury.

Table 3. Logistic regression RR and $95 \% \mathrm{CI}$ of liver injury in industrial radiographers.

\begin{tabular}{|c|c|c|c|c|c|}
\hline \multirow{2}{*}{ Covariate } & \multirow{2}{*}{$\begin{array}{l}\text { Liver Injury } \\
\text { Cases/Total } \\
\text { Participants }\end{array}$} & \multicolumn{2}{|c|}{ Model 1} & \multicolumn{2}{|c|}{ Model 2} \\
\hline & & $\mathbf{R R}$ & $95 \% \mathrm{CI}$ & $\mathbf{R R}$ & $95 \% \mathrm{CI}$ \\
\hline \multicolumn{6}{|l|}{ Sex } \\
\hline Male & $48 / 454$ & 1.0 & & 1.0 & \\
\hline Female & $4 / 54$ & 0.677 & $0.234-1.956$ & 0.949 & $0.300-3.001$ \\
\hline \multicolumn{6}{|l|}{ Age at baseline } \\
\hline$<30$ & $18 / 144$ & 1.0 & & 1.0 & \\
\hline $30-$ & $16 / 137$ & 0.926 & $0.451-1.898$ & 1.192 & $0.486-2.924$ \\
\hline $40-$ & $15 / 194$ & 0.587 & $0.285-1.208$ & 0.531 & $0.160-1.759$ \\
\hline $50-$ & $3 / 33$ & 0.700 & $0.194-2.531$ & 0.666 & $0.115-3.862$ \\
\hline \multicolumn{6}{|l|}{ Marital status } \\
\hline Single & $15 / 108$ & 1.0 & & 1.0 & \\
\hline Married/living with a partner & $25 / 255$ & 0.674 & $0.340-1.335$ & 0.993 & $0.384-2.566$ \\
\hline Divorced & $2 / 35$ & 0.376 & $0.082-1.732$ & 0.597 & $0.103-3.452$ \\
\hline Widowed & $10 / 110$ & 0.620 & $0.265-1.448$ & 0.593 & $0.204-1.727$ \\
\hline \multicolumn{6}{|l|}{ Education level } \\
\hline Junior high & $3 / 39$ & 1.0 & & 1.0 & \\
\hline High school & $25 / 265$ & 1.250 & $0.359-4.353$ & 1.309 & $0.344-4.974$ \\
\hline College & $24 / 204$ & 1.600 & $0.457-5.598$ & 1.397 & $0.336-5.811$ \\
\hline \multicolumn{6}{|l|}{ Smoking } \\
\hline Never & $24 / 284$ & 1.0 & & 1.0 & \\
\hline Occasionally & $10 / 82$ & 1.505 & $0.688-3.291$ & 1.432 & $0.630-3.254$ \\
\hline Frequently & $18 / 142$ & 1.573 & $0.823-3.005$ & 1.248 & $0.625-2.492$ \\
\hline \multicolumn{6}{|l|}{ Alcohol consumption } \\
\hline Never & $16 / 154$ & 1.0 & & 1.0 & \\
\hline Occasionally & $19 / 208$ & 0.867 & $0.430-1.747$ & 1.016 & $0.483-2.135$ \\
\hline Frequently & $17 / 146$ & 1.137 & $0.551-2.344$ & 1.394 & $0.547-3.553$ \\
\hline
\end{tabular}


Table 3. Cont.

\begin{tabular}{|c|c|c|c|c|c|}
\hline \multirow{2}{*}{ Covariate } & \multirow{2}{*}{$\begin{array}{l}\text { Liver Injury } \\
\text { Cases/Total } \\
\text { Participants }\end{array}$} & \multicolumn{2}{|c|}{ Model 1} & \multicolumn{2}{|c|}{ Model 2} \\
\hline & & RR & $95 \% \mathrm{CI}$ & $\mathbf{R R}$ & $95 \% \mathrm{CI}$ \\
\hline \multicolumn{6}{|l|}{ Hypertension } \\
\hline No & $35 / 401$ & 1.0 & & 1.0 & \\
\hline Yes & $17 / 107$ & 1.975 & $1.059-3.685^{\mathrm{a}}$ & 2.286 & $1.143-4.572^{\mathrm{a}}$ \\
\hline \multicolumn{6}{|c|}{ Cumulative recorded radiation dose } \\
\hline$>0-5.167$ & $22 / 169$ & 1.0 & & 1.0 & \\
\hline $5.168-31.540$ & $14 / 174$ & 0.585 & $0.288-1.185$ & 0.635 & $0.271-1.488$ \\
\hline $31.541-110.835$ & $16 / 165$ & 0.718 & $0.362-1.421$ & 0.998 & $0.330-3.020$ \\
\hline
\end{tabular}

Model 1: unadjusted; Model 2: Adjusted for sex, age at baseline, marital status, education level, smoking, alcohol consumption, cumulative recorded radiation dose, hypertension, diabetes; ${ }^{a} p<0.05$.

\section{Discussion}

To our knowledge, this is the first evaluation of the relationship between long-term exposure to low-dose ionizing radiation below the threshold limit value (TLV) and liver injury in industrial radiographers compared with a non-exposed group. This study complements the current risk estimates that mainly focus on high-dose or single-dose radiation exposure-induced liver injury in other studies. We found that protracted exposure to low-dose radiation was associated with liver injury. Therefore, the present study provides direct estimates of the risk of liver injury caused by protracted occupational exposure to low-dose radiation. Previous research has reported that the liver is a radiation-sensitive organ [12,14]. We found that protracted low-dose radiation exposure was a risk factor for liver injury.

We also found that sex and age were not associated with liver injury, which was in agreement with the longitudinal data collected from the atomic bomb survivors, which suggested that sex $[8,9]$ and age [9] were not associated with radiation-induced liver injury. Evidence from epidemiology studies of the general population also suggested that there was no association between age, serum ALT level [28] and liver injury [29].

Our results showed that hypertension is a risk factor for liver injury and were in agreement with previous study findings [30]. Although it is generally known that excessive alcohol consumption is a risk factor for liver disease [31,32], previous studies have confirmed that light [33] or modest alcohol consumption [34] may be a protective factor in liver injury. After adjusting for covariates, our data clearly indicated that alcohol consumption was not a risk factor. Given that the daily alcohol consumption in participants was less than medium drinking defined in previous studies [33,35], our results are in agreement with those in previous studies $[33,35]$.

No relationship between cumulative radiation dose and liver injury was found in the present study. This disagreed with the results of previous studies following exposure to high doses of radiation, which suggested that exposure to higher cumulative radiation doses results in a greater increase in ALT [36], relative risk of liver disease [5,7,9] and the severity of liver disease caused by radiation is related to the absorbed dose [37]. The observed divergence in liver function may be due to liver tolerance to ionizing radiation [36]. The total dose required to induce a tissue effect (i.e., the tolerance dose) increases if exposure occurs in smaller dose fractions or at smaller dose rates [4]. The liver has a special architecture, which allows it to tolerate a substantially higher dose of radiation prior to clinical manifestations [7]. A previous study established a tolerance level with a mean dose of <30-32 Gy (TD5) and <42 Gy (TD50) in whole-liver irradiation [38]. However, the radiographers in our study were exposed to low-dose radiation, and the follow-up period in our cohort was not long enough. The studies on atomic bomb survivors who were exposed to high-dose radiation in Japan suggested that persistent $\mathrm{HBV}$ and $\mathrm{HCV}$ infections were associated with the dose-related increase in the incidence of chronic liver disease and cirrhosis [9]. However, additional pathological studies demonstrated that atomic bomb radiation did not increase the risk of liver cirrhosis, and the prevalence of anti-HBV surface antigen and anti-HCV antibody increased in the high-dose subjects [39], but not in subjects exposed to low-dose radiation [6]. This phenomenon may explain the results in the present study. 
Direct estimates of the risk of liver injury due to protracted radiation exposure, compared with the unexposed group, is a strength of the present cohort study. According to the radiation protection requirements of our country, all the radiographers were required to wear radiation protection equipment during their employment. Because of the sufficient protection equipment and protection time, we did not analyze the impact of protection. There were many disequilibria between the exposed and control groups, so this study used a stratified analysis method to compensate for the deficiency. However, there are also limitations to this study. First, some of the individual test data were missing in previous years in this study, the cumulative radiation dose of the radiographers evaluated according to the job exposure matrix may cause measurement bias, and the individual radiation dose should be collected for further study. Second, we divided the participants into three groups based on the frequency of alcohol consumption (never, occasionally and frequently), and did not get the information of alcohol drinking volume, which may have led to bias. Finally, several other potential confounders were not examined in the study, including socioeconomic status, medications, diet and level of physical activity and exercise, which might have contributed to an under- or overestimation of the associations. However, the socioeconomic status and lifestyle were similar because the control and exposed groups lived in the same city and had the same company, thus we believe that the bias might be minimal. In addition, because the follow-up period was short and the cohort size small, it is possible that some statistically significant findings may be due to chance.

\section{Conclusions}

The present study is unique in that the risk of liver injury due to protracted exposure to low-dose radiation was estimated. The results demonstrated that protracted low-dose radiation exposure is a risk factor for liver injury. The results of the present study provide a basis for further studies on the effects of protracted low-dose radiation exposure on the liver and other systems. The societal and public health significance of the early detection and prevention of protracted low dose radiation induced occupational population hepatic injury in occupational environment is emphasized in this study.

Acknowledgments: This work was supported by the National Natural Science Foundation of China (grant number 81260424); Natural Science Foundation of Jiangsu Province, China (grant number: BK20171256); Science and Technology program of Nantong, China (NO. MS 12015111) and Nantong Science and Technology Development Funds (MS 12016054).

Author Contributions: Qing Sun, Weiming Mao interpreted the data and draft the manuscript. Haiyue Jiang and Xiaoyue Zhang validated the collected data, Jing Xiao performed the statistical analyses and edited the tables, Yulong Lian proofread the manuscript, and designed the study and revised the manuscript. All authors read and approved the final manuscript.

Conflicts of Interest: The authors declared that there is no conflict of interest in this study.

\section{Abbreviations}

The following abbreviations are used in this manuscript:

$\begin{array}{ll}\text { ALT } & \text { Alanine aminotransferase } \\ \text { AST } & \text { Aspartate transaminase } \\ \text { CDC } & \text { Center for Disease Control } \\ \text { ICRP } & \text { The International Commission on Radiological Protection } \\ \text { JEM } & \text { Job exposure matrix } \\ \text { TLD } & \text { Thermoluminescent dosimeter } \\ \text { TLV } & \text { The threshold limit value } \\ \text { ULN } & \text { The upper limit of normal } \\ \text { WHO } & \text { World health organization }\end{array}$




\section{References}

1. Nathaniel, T.N.; Sudarshan, K.; Goswami, A.; Reddy, A.V.R. Non-destructive assay technique for the determination of ${ }^{238} \mathrm{U} /{ }^{232} \mathrm{Th}$ ratio in the mixed oxides of uranium and thorium using prompt gamma-ray neutron activation. J. Radioanal. Nucl. Chem. 2009, 279, 481-485. [CrossRef]

2. Heinzl, C.; Kastner, J.; Firsching, M.; Nachtrab, F.; Uhlmann, N.; Takman, P.; Holmberg, A.; Krumm, M.; Sauerwein, C.; Lichau, D. Laboratory X-ray tomography for non-destructive testing of specimens and materials at the nanoscale. In Proceedings of the Digital Industrial Radiology and Computed Tomography, Ghent, Belgium, 22-25 June 2015.

3. Cullings, H.M. Impact on the Japanese Atomic Bomb Survivors of Radiation Received From the Bombs. Health Phys. 2014, 106, 281-293. [CrossRef] [PubMed]

4. Dorr, W. Radiobiology of tissue reactions. Ann. ICRP 2015, 44, 58-68. [CrossRef] [PubMed]

5. Walsh, L.; Grosche, B.; Schnelzer, M.; Tschense, A.; Sogl, M.; Kreuzer, M. A review of the results from the German Wismut uranium miners cohort. Radiat. Prot. Dosim. 2015, 164, 147-153. [CrossRef] [PubMed]

6. Ozasa, K.; Shimizu, Y.; Suyama, A.; Kasagi, F.; Soda, M.; Grant, E.J.; Sakata, R.; Sugiyama, H.; Kodama, K. Studies of the mortality of atomic bomb survivors, Report 14, 1950-2003: An overview of cancer and noncancer diseases. Radiat. Res. 2012, 177, 229-243. [CrossRef] [PubMed]

7. Pan, C.C.; Kavanagh, B.D.; Dawson, L.A.; Li, X.A.; Das, S.K.; Miften, M.; Ten Haken, R.K. Radiation-associated liver injury. Int. J. Radiat. Oncol. Biol. Phys. 2010, 76, S94-S100. [CrossRef] [PubMed]

8. Zielinski, J.M.; Garner, M.J.; Band, P.R.; Krewski, D.; Shilnikova, N.S.; Jiang, H.; Ashmore, P.J.; Sont, W.N.; Fair, M.E.; Letourneau, E.G.; et al. Health outcomes of low-dose ionizing radiation exposure among medical workers: A cohort study of the Canadian national dose registry of radiation workers. Int. J. Occup. Med. Environ. Health 2009, 22, 149-156. [CrossRef] [PubMed]

9. Yamada, M.; Wong, F.L.; Fujiwara, S.; Akahoshi, M.; Suzuki, G. Noncancer Disease Incidence in Atomic Bomb Survivors, 1958-1998. Radiat. Res. 2004, 161, 622-632. [CrossRef] [PubMed]

10. Liu, W.; Haley, B.M.; Kwasny, M.J.; Li, J.J.; Grdina, D.J.; Paunesku, T.; Woloschak, G.E. The Effects of Radiation and Dose-Fractionation on Cancer and Non-Tumor Disease Development. Int. J. Environ. Res. Public Health 2012, 9, 4688-4703. [CrossRef] [PubMed]

11. Abd El-Azime, A.S.; Hussein, E.M.; Ashry, O.M. Synergestic effect of aqueous purslane (Portulaca oleracea L.) extract and fish oil on radiation-induced damage in rats. Int. J. Radiat. Biol. 2014, 90, 1184-1190. [CrossRef] [PubMed]

12. Rosler, P.; Christiansen, H.; Kortmann, R.D.; Martini, C.; Matuschek, C.; Meyer, F.; Rube, C.; Langer, T.; Koch, R.; Eich, H.T.; et al. Hepatotoxicity after liver irradiation in children and adolescents: Results from the risk. Strahlenther. Onkol. Organ Deutsch. Rontgenges. 2015, 191, 413-420. [CrossRef] [PubMed]

13. Rimpler, A.; Barth, I. Radiation Protection of Staff and Public; Springer: Berlin/Heidelberg, Germany, 2012; pp. 843-852.

14. Stryker, J.A. Science to Practice: Why is the Liver a Radiosensitive Organ? Radiology 2007, 242, 1-2. [CrossRef] [PubMed]

15. Bakshi, M.V.; Azimzadeh, O.; Barjaktarovic, Z.; Kempf, S.J.; Merl-Pham, J.; Hauck, S.M.; Buratovic, S.; Eriksson, P.; Atkinson, M.J.; Tapio, S. Total Body Exposure to Low-Dose Ionizing Radiation Induces Long-Term Alterations to the Liver Proteome of Neonatally Exposed Mice. J. Proteome Res. 2015, 14, 366-373. [CrossRef] [PubMed]

16. Dufour, D.R.; Lott, J.A.; Nolte, F.S.; Gretch, D.R.; Koff, R.S.; Seeff, L.B. Diagnosis and monitoring of hepatic injury. I. Performance characteristics of laboratory tests. Clin. Chem. 2000, 46, 2027-2049. [PubMed]

17. Kim, W.R.; Flamm, S.L.; Di Bisceglie, A.M.; Bodenheimer, H.C. Public Policy Committee of the American Association for the Study of Liver, D. Serum activity of alanine aminotransferase (ALT) as an indicator of health and disease. Hepatology 2008, 47, 1363-1370. [CrossRef] [PubMed]

18. Kim, H.C.; Nam, C.M.; Jee, S.H.; Han, K.H.; Oh, D.K.; Suh, I. Normal serum aminotransferase concentration and risk of mortality from liver diseases: Prospective cohort study. BMJ 2004, 328, 983. [CrossRef] [PubMed]

19. Gong, X.; Yang, J.; Tang, J.; Gu, C.; Huang, L.; Zheng, Y.; Liang, H.; Wang, M.; Wu, C.; Chen, Y.; et al. A Mechanistic Assessment of the Discordance between Normal Serum Alanine Aminotransferase Levels and Altered Liver Histology in Chronic Hepatitis B. PLoS ONE 2015, 10, e0134532. [CrossRef] [PubMed] 
20. Malaguarnera, G.; Cataudella, E.; Giordano, M.; Nunnari, G.; Chisari, G.; Malaguarnera, M. Toxic hepatitis in occupational exposure to solvents. World J. Gastroenterol. 2012, 18, 2756-2766. [CrossRef] [PubMed]

21. Sarin, S.K.; Kumar, M.; Lau, G.K.; Abbas, Z.; Chan, H.L.Y.; Chen, C.J.; Chen, D.S.; Chen, H.L.; Chen, P.J.; Chien, R.N. Asian-Pacific clinical practice guidelines on the management of hepatitis B: A 2015 update. Hepatol. Int. 2016, 10, 1-98. [CrossRef] [PubMed]

22. Lopez, A.M.; Hendrickson, R.G. Toxin-induced hepatic injury. Emerg. Med. Clin. N. Am. 2014, $32,103$. [CrossRef] [PubMed]

23. Choi, S.; Kang, D.; Park, D.; Lee, H.; Choi, B. Developing Asbestos Job Exposure Matrix Using Occupation and Industry Specific Exposure Data (1984-2008) in Republic of Korea. Saf. Health Work 2017, 8, 105-115. [CrossRef] [PubMed]

24. Ilar, A.; Alfredsson, L.; Wiebert, P.; Klareskog, L.; Bengtsson, C. Airborne Occupational Exposures and Risk of Developing Rheumatoid Arthritis: A Job-Exposure Matrix Approach in a Swedish Population-Based Case-Control Study. Arthritis Care Res. 2017. [CrossRef] [PubMed]

25. Schnall, P.L.; Schwartz, J.E.; Landsbergis, P.A.; Warren, K.; Pickering, T.G. A longitudinal study of job strain and ambulatory blood pressure: Results from a three-year follow-up. Psychosom. Med. 1998, 60, 697-706. [CrossRef] [PubMed]

26. Hanson, L.L.; Akerstedt, T.; Näswall, K.; Leineweber, C.; Theorell, T.; Westerlund, H. Cross-Lagged Relationships Between Workplace Demands, Control, Support, and Sleep Problems. Sleep 2011, 34, 1403-1410. [CrossRef] [PubMed]

27. World Health Organization. 2015 Global Reference List of 100 Core Health Indicators; World Health Organization: Geneva, Switzerland, 2015.

28. Mohamadnejad, M.; Pourshams, A.; Malekzadeh, R.; Mohamadkhani, A.; Rajabiani, A.; Asgari, A.A.; Alimohamadi, S.M.; Razjooyan, H.; Mamar-Abadi, M. Healthy ranges of serum alanine aminotransferase levels in Iranian blood donors. World J. Gastroenterol. 2003, 9, 2322-2324. [CrossRef] [PubMed]

29. Gray, E.L.; Goldberg, H.F. Baseline abnormal liver function tests are more important than age in the development of isoniazid-induced hepatoxicity for patients receiving preventive therapy for latent tuberculosis infection. Intern. Med. J. 2016, 46, 281-287. [CrossRef] [PubMed]

30. Diehl, A.M.; Goodman, Z.; Ishak, K.G. Alcohollike liver disease in nonalcoholics. A clinical and histologic comparison with alcohol-induced liver injury. Gastroenterol. 1988, 95, 1056-1062. [CrossRef]

31. Vatsalya, V.; Song, M.; Schwandt, M.L.; Cave, M.C.; Barve, S.S.; George, D.T.; Ramchandani, V.A.; McClain, C.J. Effects of Sex, Drinking History, and Omega-3 and Omega-6 Fatty Acids Dysregulation on the Onset of Liver Injury in Very Heavy Drinking Alcohol-Dependent Patients. Alcohol. Clin. Exp. Res. 2016, 40, 2085-2093. [CrossRef] [PubMed]

32. Tokarskaya, Z.B.; Zhuntova, G.V.; Scott, B.R.; Khokhryakov, V.F.; Belyaeva, Z.D.; Vasilenko, E.K.; Syrchikov, V.A. Influence of alpha and gamma radiations and non-radiation risk factors on the incidence of malignant liver tumors among Mayak PA workers. Health Phys. 2006, 91, 296-310. [CrossRef] [PubMed]

33. Sogabe, M.; Okahisa, T.; Nakagawa, T.; Fukuno, H.; Nakasono, M.; Tomonari, T.; Tanaka, T.; Tanaka, H.; Taniguchi, T.; Muguruma, N. Influence of light alcohol consumption on lifestyle-related diseases: A predictor of fatty liver with liver enzyme elevation in Japanese females with metabolic syndrome. BMC Gastroenterol. 2016, 16, 17. [CrossRef] [PubMed]

34. Dunn, W.; Sanyal, A.J.; Brunt, E.M.; Unalp-Arida, A.; Donohue, M.; McCullough, A.J.; Schwimmer, J.B. Modest alcohol consumption is associated with decreased prevalence of steatohepatitis in patients with non-alcoholic fatty liver disease (NAFLD). J. Hepatol. 2012, 57, 384-391. [CrossRef] [PubMed]

35. Moriya, A.; Iwasaki, Y.; Ohguchi, S.; Kayashima, E.; Mitsumune, T.; Taniguchi, H.; Ikeda, F.; Shiratori, Y.; Yamamoto, K. Alcohol consumption appears to protect against non-alcoholic fatty liver disease. Aliment. Pharmacol. Ther. 2011, 33, 378-388. [CrossRef] [PubMed]

36. Nwokocha, C.R.; Nwokocha, M.; Mounmbegna, P.; Orhue, J.; Onyezuligbo, O.; Olu-Osifo, E.H.; Okojie, E.; Asuquo, E.; Ejimofor, T.; Ikenna, N.; et al. Proteins and liver function changes in rats following cumulative total body irradiations. West Indian Med. J. 2012, 61, 773-777. [PubMed]

37. Okamoto, D.; Nishie, A.; Asayama, Y.; Tajima, T.; Ishigami, K.; Kakihara, D.; Nakayama, T.; Ohga, S.; Yoshitake, T.; Shioyama, Y.; et al. Gadolinium ethoxybenzyl diethylenetriamine pentaacetic acid-enhanced MR finding of radiation-induced hepatic injury: Relationship to absorbed dose and time course after irradiation. Magn. Reson. Imaging 2014, 32, 660-664. [CrossRef] [PubMed] 
38. Marks, L.B.; Yorke, E.D.; Jackson, A.; Haken, R.K.T.; Constine, L.S.; Eisbruch, A.; Bentzen, S.M.; Nam, J.; Deasy, J.O. The Use of Normal Tissue Complication Probability (NTCP) Models in the Clinic. Int. J. Radiat. Oncol. Biol. Phys. 2010, 76, S10-S19. [CrossRef] [PubMed]

39. Fujiwara, S.; Kusumi, S.; Cologne, J.; Akahoshi, M.; Kodama, K.; Yoshizawa, H. Prevalence of Anti-Hepatitis C Virus Aantibody and Chronic Liver Disease among Atomic Bomb Survivors. Radiat. Res. 2000, 154, 12-19. [CrossRef]

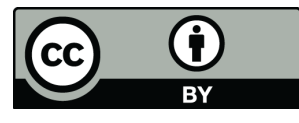

(C) 2018 by the authors. Licensee MDPI, Basel, Switzerland. This article is an open access article distributed under the terms and conditions of the Creative Commons Attribution (CC BY) license (http:/ / creativecommons.org/licenses/by/4.0/). 